\title{
Price Caps and Electoral Cycles
}

Cesar Costa Mattos*

\begin{abstract}
This paper presents a model about the behavior of politicians in tariff reviews within the context of price cap regulation with different hypothesis of the election calendar. We address both the cases of backward and forward looking voters. The model shows that there is a natural tendency, when voters are backwardlooking, for politicians to be relatively more populist when price cap reviews occur just before elections and relatively more pro-entrepreneur when these reviews occur just after elections. This can make the politician's rule closer or not to the rule attributed to the benevolent regulator. For originally populist politicians, it would be better to have price cap reviews happening just after elections, while for pro-entrepreneur politicians, it would be preferable to have price caps occurring just before elections. On the other hand, we also show that when voters are forward-looking, politicians always tend to be more pro-entrepreneur. The political independence of the regulator matters relatively more when voters are forward-looking and in specific combinations of election timing and politicians original preferences toward consumers and firms.
\end{abstract}

Keyw ords: Price Caps, Electoral Cycles, Populism, Capture.

Resumo: Este artigo apresenta um modelo sobre o comportamento de políticos em revisões tarifárias no contexto de uma regulação de price cap com diferentes hipóteses sobre o calendário eleitoral. Avaliamos tanto o caso de eleitores cujas expectativas são construídas olhando para trás como para frente. O modelo mostra haver uma tendência natural de os políticos serem relativamente mais populistas quando os eleitores "olham para trás" e as revisões dos price caps ocorrem pouco antes das eleições. $O$ contrário se verifica quando as revisões ocorrem logo após as eleições, com os políticos se tornando viesados em favor dos empresários. Estas tendências podem fazer com que a regra ótima de revisão tarifária do ponto de vista do político mais próxima ou mais distante daquela que seria escolhida por um regulador benevolente. Para políticoscom preferências populistas, seria melhor ter revisões ocorrendo logo após as eleições, enquanto que para políticos mais pró-empresários, se torna preferível ter revisões ocorrendo um pouco antes das eleições. De outro lado, quando os eleitores "olham para a frente", todos os políticos tendem a ser mais pró-empresários. A independência do regulador se torna mais importante quando os eleitores "olham para a frente" e em combinações específicas das preferências dos políticose do momento da revisão relativamente à eleição.

Palavras Chave: price caps, ciclos eleitorais, populismo, captura

J EL Classification: D72, D78, E32, L51

* Conselheiro do CADE e Doutor em Economia. E-mail: cesar.mattos@camara.gov.br. 


\section{Introduction}

The traditional regulation of utility companies around the world in the past was based on a maximum allowed rate of return over capital. The decades of 80 and 90 witnessed a gradual worldwide change from the classical rate of return regulation used in the US to the price cap regulation introduced in the UK just after the privatization of the British Telecom. This method was defended in the famous "Littlechild Report" from 1983, becoming the most important method of price regulation in all (recently privatized) utility sectors in that country. ${ }^{1}$ The FCC in the US adopted the price caps for interstate calls in 1989. ${ }^{2}$ The regulation of other regulated utilities around the world such as electric power, gas, sanitation and railways became also based on price caps.

Acton and Vogelsang (1989) provide an earlier survey of the economic literature about price caps. The general consensus was that price caps would be a superior solution to rate of return regulation. The authors (p.370) characterise price cap regulation on the basis of four properties: " 1 . The regulator directly sets a ceiling for prices to be charged by the regulated firm. The firm may choose prices below the ceiling; 2.Price ceilings are defined for baskets of services offered by the regulated firm. They can be expressed as price indices for these baskets-and different ceilings may apply to each basket; 3.These price indices are adjusted periodically by a preannounced adjustment factor that is exogenous to the regulated firm; 4.In longer intervals of several years, the adjustment factors, baskets, and weighting schemes for the indices are reviewed and possibly changed". While all of these properties had already been discussed in the economic literature until that time as shown by the authors (p. 370), the British innovation was to combine these four elements in shaping the new UK regulatory policy that influenced all regulatory practice around the world. ${ }^{3}$

The price cap rule requires that the average rate of growth of the regulated prices be limited to the rate of change of a price index

\footnotetext{
1 For more details in the origins of the price cap in the UK, see Vickers and Yarrow (1988, p.205/ 208), Armstrong, Cowan and Vickers (ACV-1994, p.166/174) and Beesley and Littlechild (1997).

2 On the other hand, as shown by Mitchell and Vogelsang (1991,p. 17), at least until 1991, the US State Public Utility commissions continued regulating prices based on rate of return regulation for state, inter-LATA and Intra-LATA long distance calls.

3 See the remaining of this issue of the Rand J ournal in 1989 for other papers on the economic properties of price caps.
} 
(in the case of UK, the Retail Price Index-RPI, the basic consumer price index in this country) less an exogenous factor named $X$, which is generally regarded as an estimation of the future productivity increase of the sector, allowing for real price decreases. This is the "RPI-X" formula. One of the main appeals of the price-cap rule is its simplicity, reducing the information requirements to be implemented in comparison to rate of return regulation.

It is important to understand the difference between price-cap and rate of return regulation based on the fundamental trade-off between the regulator objectives of providing incentives for cost reduction and of extracting rents from the regulated firm. Most of the recent regulatory literature including, for instance, the textbook of Laffont and Tirole (1993) is concerned with this issue. In the case of rate of return regulation as long as cost expenses can be (at least partially) recouped through higher prices, there is not much concern from the company to reduce its costs. On the other hand, the regulator has a great ability to extract any rents he/she wishes from the firm, since every cost saving the company obtains will have to be transferred to (lower) prices and thus to consumers. Rate of return regulation is considered a low-powered incentive regulatory schemes.

In the case of price cap regulation, the regulator does not have any ability to extract rents ex-post, since any cost saving can accrue to company profits without any requirement of lowering prices. Because of full appropriation of its cost savings, the firms have a strong incentive to reduce costs, becoming more efficient. Given the high incentives for efficiency, the price cap is considered a highpowered incentive regulatory scheme and the regulated firm becomes the residual claimant of its cost savings. In sum, rate of return regulation is very good for the purposes of rent extraction, but very bad for efficiency, while price cap regulation is very good for efficiency and not so good for rent extraction. Thus, the adoption of a pure price cap regulation reveals a strong preference of the regulator toward efficiency relatively to rent extraction.

These considerations neglect the role of politics on the success of price cap regulation. The most relevant political influence that has been treated in the economic literature refers to the capacity of commitment of the regulator about the "rules of the game". This relates closely to the regulator's credibility. ${ }^{4}$ There are natural pressures from the public and from politicians for making the cap tighter than

4 See the book of Levy and Spiller (1996) for the relevance of the institutional endowments of several countries for their credibility and for the optimal institutional design. 
previously agreed before the original term for renewal after observing that the company obtained high profits. Sappington and Weisman (1996, p.181) present this problem: "The higher earnings that can arise under many incentive regulation plans can invite ratepayer displeasure. Even if pronounced earnings are due entirely to the firm's diligent efforts and business acumen, and not to lax regulations or fortuitous events beyond the firm's control, ratepayers may regard high earnings as unfair". ${ }^{5}$

Another dimension of the influence of politics on tariff reviews is the preferences of the regulator towards regulated firms vis-à-vis consumers. The classical paper of Peltzman (1976) presents a simple framew ork based on the idea that politicians maximize their chances of being re-elected. This model, however, does not consider the impact of time on politician's behaviour. In this regard, a new body of literature based on electoral cycles have been developed. According to a recent survey made by Ogura (2000), the electoral cycles, from an economic point of view, are related to the correlation of economic and/or policy variables closed to the period of elections caused by an opportunist behaviour of the politician aiming to improve his likelihood of being re-elected. The main theoretical models of electoral cycles, are by Nordhaus (1975), Rogoff and Sibert (1988) and Rogoff (1990). The first paper supposes voters with adaptive expectations and thus backward looking behaviour, while the other two assume rational expectations and thus a forward looking behaviour.

Nordhaus (1975) shows that politicians tend to stimulate the economy in the pre-electoral period, turning to recessive policies afterwards. The new wave of rational expectation models, consistently with other branches of macroeconomics, argued that, if pre-electoral expansionist policies were perfectly anticipated by voters, there would be no real impact in the economy. In this

\footnotetext{
Regulators often have to deal with the accusation of being benevolent to the company because of the high profits provided by the price cap, explaining why it is not capture but part of a welfare enhancing mechanism. We can see this explicitly in Oftel (march, 2000): "Price cap controls in the form of RPI-X formulae have been applied to BT's retail prices since 1984, and BT's network (interconnection) charges since 1997. During that time, there has sometimes been criticism of the level of profit earned by $\mathrm{BT}$, and so it could be argued that there should be direct controls on the profitability of BT, or mechanisms for direct profit sharing during the life of a price cap". After explaining the basic mechanism of price cap, Oftel concludes that "high profitability in a price capped firm at any given time is not therefore necessarily a cause for concern and might simply be a consequence of the firm having been successful in reducing costs faster than is required by the cap. These cost reductions will ultimately benefit customers through lower prices".
} 
sense, cycles would only occur by introducing some type of imperfect information of the voters relatively to the skills of the government. Politicians in charge, acting opportunistically on the basis of this lack of information, signals that they are high-skilled public managers aiming to win election and then the electoral cycle is back.

In this article, we model the dependence of tariff reviews in the context of a price cap system on the election cycle. What makes price cap systems different from other schemes of tariff reviews is that the definition of the " $X$ " factors of the price caps are established for several years ahead. In the case of the UK, for instance, the X factors of the price caps were defined for a minimum of three-year term in the beginning of the period as shown in the table below.

Table 1 - Historical X Values in the UK Price Cap Regulation in Telecommunication

\begin{tabular}{c|c}
\hline Period & X Value \\
\hline $1984 / 89$ & 3 \\
\hline $1989 / 91$ & 4,5 \\
\hline 199193 & 6,25 \\
\hline $1993 / 97$ & 7,5 \\
\hline $1997 / 01$ & 4,5 \\
\hline
\end{tabular}

The exogeneity of price cap reviews makes the date of review of the $X$ factors particularly relevant in the electoral cycle. In this article, we assume a model of two periods and two possible dates of $X$ factors reviews. The main difference of this paper compared to the previous literature is that, being the voters backward or forward-looking, the maximization that matters for politicians always occur by the time of the elections and not by the time of the $X$ factor review. This brings interesting results and also makes the extension for forward looking agents in this model straightforward.

The model will also address the question of how important the independence of the regulatory body from politicians is for the sake of maximizing social welfare.

The importance of this analysis for Brazil is particularly concentrated to the sector of telecommunications where price caps were actually introduced to regulated the recent privatised companies in 1998. Furthermore, there is also an interest in the country for the 
sake of discussing the institutional design of the regulatory agencies. The Executive branch sent a bill to Congress, ${ }^{6}$ proposing a change in some specific features of the agencies that are treated by this article. Two issues are of particular relevance. First, the bill is based on a former Report (2003) in which a presumed "excessive independence" of the agencies is taken as potentially damaging. Second, the bill imposes a syncronicity between the mandates of regulators and the President of the country: the bill establishes that the mandates of all commissioners finish between J anuary, $1^{\text {st }}$ and J une, $30^{\text {th }}$ of the second year of the President's mandate. ${ }^{7}$

In the next section, we present the basic setting and the behaviour of the benevolent regulator that will be the benchmark of the analysis. Section III introduces political behaviour. After some general remarks about politician behaviour in sub-section III-a, we work the hypothesis of a price cap tariff review in the middle of the period between elections and check for the tendency towards a populist behaviour when voters are backward-looking in sub-section III-b. Sub-section III-c addresses a tariff review just after an election and check for the tendency towards a pro-entrepreneur behaviour, maintaining the hypothesis of backward-looking voters. Section III-d addresses the behaviour of politicians when voters are forward-looking. Section IV concludes.

\section{The Basic M odel and the Benevolent Regulator}

We use a two-periods model. The time between two tariff reviews includes these two periods. We assume that the time between elections is within these two periods. However, the two periods do not need to coincide with the time between elections. For the sake of simplicity, we assume that there are two possible moments when the election can occur: I) just after the second period or; II) between the periods. The timeline below illustrates both hypotheses:

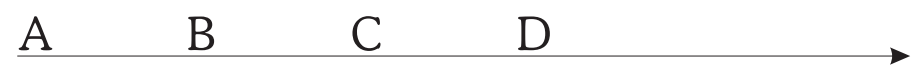

Figure 1 - Schedule of Tariff Reviews and Elections

Tariff Reviews at $A$ and $C$ after $\mathrm{C}$

First Case: election at $B$ between $A$ and $C$, and then goes until $D$

Second Case: election just before $\mathrm{A}$ and $\mathrm{C}$

\footnotetext{
6 Projeto de Lei № 3.337/04.

7 For a critical assessment of the bill, see Mueller and Mattos (2004).
} 
We have the following relevant variables: $S_{1}\left(p_{1}\left(x_{1}\right)\right)$ and $S_{2}\left(p_{2}\left(x_{2}\right)\right)$ are the consumer surpluses associated to periods 1 and 2, respectively. Both depends on the respective prices, $p_{1}$ and $p_{2}$, in each period. At the same time, $p_{1}$ and $p_{2}$ depend on a period-specific cost parameter $x_{1}$ and $x_{2}$, respectively. $r$ is the intertemporal discount rate, which we suppose to be the same for firms and consumers. Then, in period " 0 ", consumers maximize their surplus in two periods:

$$
S=S_{1}\left(p_{1}\left(x_{1}\right)\right)+\frac{S_{2}\left(p_{2}\left(x_{2}\right)\right)}{1+r}
$$

$\partial \mathrm{St} / \partial \mathrm{pt} \leq 0$ and $\partial \mathrm{St} / \partial \mathrm{pt} \geq 0$ for $\mathrm{t}=1,2$ in the relevant range

The regulated firm has the following two-period profit function to maximize:

$$
\Pi=\pi_{1}\left(p_{1}\left(x_{1}\right), x_{1}\right)+\frac{\pi_{2}\left(p_{2}\left(x_{2}\left(I_{1}\right)\right)\right)}{1+r}
$$

$\partial \pi \mathrm{t} / \partial \mathrm{pt}{ }^{3} 0 \partial^{2} \pi \mathrm{t} / \partial \mathrm{pt}^{2} \leq 0$ for $\mathrm{t}=1,2$ in the relevant range $\pi_{1}\left(p_{1}\left(x_{1}\right), x_{1}\right)$ and $\pi_{2}\left(p_{2}\left(x_{2}\left(I_{1}\right)\right), x_{2}\left(I_{1}\right)\right)$ are the profits in each period and both will be positive concave functions of the prices in their respective period. Profits in both periods are negative functions of the cost parameter $x_{t}$ for $t=1,2$, being $d \pi_{t} / d x_{t}=\partial \pi_{t} / \partial p_{t}\left(\partial p_{t} / \partial x_{t}\right)+\partial \pi_{t} /$ $\partial x_{t} \leq 0,{ }^{8}$ since the negative direct effect of the costs on profits is certainly higher than the (positive) indirect impact through prices. In other words, it would not be reasonable to have profits increasing in the cost parameter.

Variable $I_{1}$ corresponds to the investment made by the firm in the first period, but that will only bring some impact on costs in the second period. Even being undertaken by the firm, we assume, since this is a regulated sector, that the regulator also chooses the optimal value of the investment $I_{1}$. We assume that $\partial x_{2} / \partial I_{1} \leq 0$ and $\partial x_{1} / \partial I_{1}=0$. Thus, while $x_{1}$ is fixed in the two-period model, $x_{2}$ will decrease with the increase in $I_{1}$. As the model only comprises 2 periods, there will never be investment in period 2 .

\footnotetext{
This formulation encompasses a broad range of functional forms. Now, we provide an example with a linear demand form. If $q(p)=a-b p$ and $\pi=p q(p)-x q(p) . \quad \partial \pi / \partial p=a-2 b p$ $+x b=0$. So, $p=(a+x b) / 2 b$ and $\partial p / \partial x=1 / 2 .(\partial \pi / \partial p) \partial p / \partial x=1 / 2^{*}(a-2 b p+x b)$ and $\partial \pi / \partial x=-a$. $\mathrm{d} \pi / \mathrm{dx}=(\partial \pi / \partial \mathrm{p}) \partial \mathrm{p} / \partial \mathrm{x}+\partial \pi / \partial \mathrm{x}=1 / 2(a-2 b p+x b)-a$. We suppose that $\mathrm{a} \geq 1 / 2(a-2 b p+x b)$ or $a / 2 \geq b(x / 2-p)$ over all the relevant range.
} 
We make a very important assumption: There is no capital market that links the two periods, but only within each period. Therefore, the sole source of resources for investment in period 1, are the profits generated in period one ${ }^{9}$ and we can define the following constraint of the model:

$$
\pi_{1}\left(p_{1}\left(x_{1}\right), x_{1}\right) \geq I_{1}
$$

First, we assume a regulatory body that acts as a benevolent regulator completely independent from politicians, making $\$ 1$ of profits equals to $\$ 1$ of consumer surplus in his objective function in the two periods, discounting the second one by $1+r$. Moreover, we can suppose two hypothesis with the same effect: 1) we are working on a transition time after a privatization where prices and investment are regulated in period 1, but fully liberalized in period 2 and thus the variable choices of the regulator at date $A$ are only first period ones; 2 ) the regulator is not able to commit himself to prices in period 2 when he chooses price and investment for period 1 . From one of the both hypothesis, we have that the regulator only chooses $p_{1}$ and $I_{1}$. Therefore, the utility of the regulator $\left(U_{r}\right)$ is: ${ }^{10}$

$$
U_{r}=S_{1}\left(p_{1}\left(x_{1}\right)\right)+\pi_{1}\left(p_{1}\right)-I_{1}+\frac{\left[S_{2}\left(p_{2}\left(x_{2}\left(I_{1}\right)\right)\right)+\pi_{2}\left(p_{2}\left(x_{2}\left(I_{1}\right)\right), x_{2}\left(I_{1}\right)\right)\right]}{1+r}
$$

We maximize (4) subject to (3). The choice variables are the regulated price and investment of period 1 . Thus, we have the following Lagrangian:

$$
\begin{aligned}
& L_{r}=S_{1}\left(p_{1}\right)+\pi_{1}\left(p_{1}\right)-I_{1}+\frac{\left[S_{2}\left(p_{2}\left(x_{2}\left(I_{1}\right)\right)\right)+\pi_{2}\left(p_{2}\left(x_{2}\left(I_{1}\right)\right), x_{2}\left(I_{1}\right)\right)\right]}{(1+r)}+\lambda_{r}\left(\pi_{1}\left(p_{1}\right)-I_{1}\right) \\
& P_{1}, I_{1}
\end{aligned}
$$

We assume that there are only interior solutions for $p_{1}$, but not for $I_{1}$. The first-order conditions are:

\footnotetext{
9 It does not mean that there are not capital markets at all, since the firm can take a loan in the very beginning of the first period to be paid in the end of this period. So, we are discharging long-run capital markets, but not short-run ones.

10 For notational simplicity, we will not explicit $x_{1}$ from now on.
} 


$$
\begin{aligned}
& \frac{\partial L_{r}}{\partial p_{1}{ }^{r}}=S_{1}{ }^{\prime}\left(p_{1}^{r}\right)+\pi_{1}{ }^{\prime}\left(p_{1}{ }^{r}\right)+\lambda_{r} \pi_{1}{ }^{\prime}\left(p_{1}{ }^{r}\right)=0 \\
& \frac{\partial L_{r}}{\partial I_{1}} I_{1}=\left[\frac{\frac{\partial \pi_{2}}{\partial x_{2}} * \frac{\partial x_{2}}{\partial I_{1}}+\frac{\partial \pi_{2}}{\partial p_{2}} * \frac{\partial x_{2}}{\partial I_{1}}+\frac{\partial S_{2}}{\partial p_{2}} \frac{\partial p_{2}}{\partial x_{2}} \frac{\partial x_{2}}{\partial I_{1}}}{1+r}-1-\lambda_{r}\right] I_{1}=0 \\
& \frac{\partial L_{r}}{\partial \lambda_{r}} * \lambda_{r}=\left(\pi\left(p_{1}\right)-I_{1}\right) \lambda_{r}
\end{aligned}
$$

The first condition results in

$$
\pi_{1}{ }^{\prime}\left(p_{1}^{r}\right)=\frac{-S_{1}{ }^{\prime}\left(p_{1}^{r}\right)}{1+\lambda_{r}}
$$

Notice that $\left[\left(\partial \pi_{2} / \partial \mathrm{x}_{2}\right) \partial \mathrm{x}_{2} / \partial \mathrm{I}_{1}+\left(\partial \pi_{2} / \partial \mathrm{p}_{2}\right)\left(\partial \mathrm{p}_{2} / \partial \mathrm{x}_{2}\right)\left(\partial \mathrm{x}_{2} / \partial \mathrm{I}_{1}\right)\right]=\mathrm{d} \pi_{2} / \mathrm{dl}_{1}$ and $\left(\partial \mathrm{S}_{2} / \partial \mathrm{p}_{2}\right)\left(\partial \mathrm{p}_{2} / \partial \mathrm{x}_{2}\right)\left(\partial \mathrm{x}_{2} / \partial \mathrm{I}_{1}\right)=\mathrm{dS}_{2} / \mathrm{dl}_{1}^{2}$

Concerning the first-order condition on investment, we can have two hypothesis, $\lambda_{r} \neq 0$ or $\lambda_{r}=0$. In the first hypothesis the investment constraint is binding and thus all first period profits are carried out to fund investment. In this case,

$$
\lambda_{r}=\frac{\left[\frac{d \pi_{2}}{d I_{1}}+\frac{d S_{2}}{d I_{1}}\right]}{1+r}-1
$$

And replacing (7) in (6) above we get:

$$
\pi_{1}{ }^{\prime}\left(p_{1}^{r}\right)=\frac{-S_{1}{ }^{\prime}\left(p_{1}^{r}\right)(1+r)}{\frac{d \pi_{2}}{d I_{1}}+\frac{d S_{2}}{d I_{1}}}
$$

Equation (8) gives the regulated price chosen by the benevolent regulator if the constraint is binding. As $\left(\partial \pi_{2} / \partial x_{2}\right) \leq 0$ (profit decreases with the cost parameter) and $\partial x_{2} / \partial I_{1} \leq 0$ (the cost parameter decreases with the investment), $\left[\left(\partial \pi_{2} / \partial x_{2}\right) \partial x_{2} / \partial I_{1}\right] \geq 0$. As $\partial \pi_{2} / \partial p_{2} \geq 0, \partial p_{2} / \partial x_{2} \geq 0$ and $\partial \mathrm{x}_{2} / \partial \mathrm{I}_{1} \leq 0$, then $\left(\partial \pi_{2} / \partial \mathrm{p}_{2}\right)\left(\partial \mathrm{p}_{2} / \partial \mathrm{x}_{2}\right)\left(\partial \mathrm{x}_{2} / \partial \mathrm{I}_{1}\right) \leq 0$. We suppose that 
investment in period 1 has a positive impact in the profit of period 2 $\left(\mathrm{d} \pi_{2} / \mathrm{dl}_{1} \geq 0\right)$. Otherwise, the firm would never invest and the insertion of this variable in the model would be meaningless. Thus, we have that $\left(\partial \pi_{2} / \partial \mathrm{p}_{2}\right)\left(\partial \mathrm{p}_{2} / \partial \mathrm{x}_{2}\right)\left(\partial \mathrm{x}_{2} / \partial \mathrm{I}_{1}\right) \leq\left[\left(\partial \pi_{2} / \partial \mathrm{x}_{2}\right) \partial \mathrm{x}_{2} / \partial \mathrm{I}_{1}\right]$, the direct impact of the investment over the cost parameter $x_{2}$ outweighs the indirect effect of the price decrease resulting from the cost saving. At the same time, as $\left(\partial \mathrm{S}_{2} / \partial \mathrm{p}_{2}\right) \leq 0,\left(\partial \mathrm{p}_{2} / \partial \mathrm{x}_{2}\right) \geq 0$ and $\left(\partial \mathrm{x}_{2} / \partial \mathrm{I}_{1}\right) \leq 0$, we have that $\mathrm{dS}_{2} / \mathrm{dl}_{1} \geq 0$.

Knowing that $S_{1}{ }^{\prime}\left(p_{1}\right)<0$ (consumer surplus decreases with prices), we have that $\left(\partial \pi_{1} / \partial p_{1}\right) \geq 0$. Thus, $p_{1}{ }^{r} \leq p_{1}{ }^{m}$, the regulated price $p_{1}{ }^{r}$ is lower or equal than the price that would be settled by the regulated firm without intervention $\left(\mathrm{p}_{1}{ }^{\mathrm{m}}\right)$. Thus, the regulated price will be a binding constraint for the firm.

Moreover, the higher the impact of the investment in the cost parameter, the lower $\left(\partial \pi_{1} / \partial p_{1^{*}}\right)$. This happens through the effects on profits and consumer surplus in period 2 . Observe that as the effect of the investment in period 1 in the profit of the period 2 increases, $\left(\partial \pi_{1} / \partial p_{1^{*}}\right)$ is reduced, implying a higher regulated price as profits are assumed to be concave functions of prices. In other words, as the effect of investment on cost is high, the benevolent regulator accepts a high price to raise funds for this investment that can increase profits and consumer surplus in the second period.

The effect of the discount rate is intuitive. The higher the value of the current consumption compared to the second period consumption, the lower will be the first period price.

Under the second hypothesis when the investment constraint is not binding, $\lambda_{r}=0$ and from (6), we get:

$$
\pi_{1}{ }^{\prime}\left(p_{1}^{r}\right)=-S_{1}{ }^{\prime}\left(p_{1}^{r}\right)
$$

The economic interpretation of ( $\left.6^{\prime}\right)$ is straightforward. If there is no value in increasing second period welfare by augmenting the first period profits and thus investment since the constraint is not binding, $\$ 1$ of consumer surplus equals $\$ 1$ of profits in the benevolent regulator objective function. Therefore, the first and second period components of the objective functions will be, in equilibrium, solved separately under this hypothesis. Equation ( $\left.6^{\prime}\right)$ tells us that the optimum regulated price will be settled to equate the marginal effect of its change on profits and consumer surplus, which is equivalent to maximize the sum of these variables. 


\section{Introducing Politicians}

\section{1 $\mathrm{G}$ eneral Remarks}

Now, we introduce the politician problem. We follow the models that suppose politicians maximizing their re-election likelihood following the classic paper of Peltzman (1976). The important change from the benevolent regulator problem is the inclusion of explicit relative weights for consumer satisfaction and profits. As the majority of consumers vote in the elections, the politician will be concerned about their satisfaction, since they may be translated in votes. On the other hand, the entrepreneurs of the regulated firms provide campaign funds to the politician, which can be also translated into votes.

The objective function of the politician will depend on his perception about which agents matter more for his re-election. In the case of the Congressman, this perception will be affected by the degree of consumer monitoring of his work on the regulatory hearings and his behavior in the relevant Congress commission. ${ }^{11}$ If the tariffs are settled directly by the executive branch, the impact of consumer satisfaction on votes tends to be more straightforward. We assume that the politician aggregates consumer satisfaction and profits in a linear objective function weighted by $\alpha$ and (1- $\alpha)$, respectively.

Another important consideration regards the way consumers and entrepreneurs behave at the date of the election. We can have two distinct hypothesis concerning the objective function of the politicians, depending on the timing of the elections vis-a-vis the moment of the tariff review. The first one occurs when elections happen in the end of the first period and the second one, when elections occur at the end of the second period. The next sub-section shows the first case while sub-section III.c presents the second case.

\subsection{Politician A : Election in the End of the First Period}

First, the election can occur in the transition between the 2 periods (first case of Figure 1 ). Then, politician A maximizes only the first period variables.

$$
U_{p o l A}=\alpha S_{1}\left(p_{1}\right)+(1-\alpha)\left(\pi_{1}\left(p_{1}\right)-I_{1}\right)+\lambda_{p o l A}\left(\pi_{1}\left(p_{1}\right)-I_{1}\right)
$$

\footnotetext{
${ }^{11}$ See Shepsle and Weinsgat (1987) for the important role of the commissions in Congress.
} 


$$
\begin{aligned}
& \frac{\partial U_{p o l A}}{\partial p_{1}}=\alpha S_{1}{ }^{\prime}\left(p_{1}{ }^{\text {polA }}\right)+(1-\alpha) \pi_{1}{ }^{\prime}\left(p_{1}{ }^{\text {polA }}\right)+\lambda_{p o l A} \pi_{1}{ }^{\prime}\left(p_{1}{ }^{\text {polA }}\right)=0 \\
& \frac{\partial U_{p o l A}}{\partial \lambda_{\text {polA }}} \lambda_{p o l A}=\left(\pi_{1}\left(p_{1}\right)-I_{1}\right) \lambda_{p o l A}=0
\end{aligned}
$$
implies

There are two hypothesis, $\lambda_{\text {polA }} \neq 0$ and $\lambda_{\text {polA }}=0$. The first hypothesis

$$
\pi^{\prime}\left(p_{1}{ }^{\text {polA }}\right)=\frac{-\alpha S_{1}{ }^{\prime}\left(p_{1}{ }^{\text {polA }}\right)}{\left[(1-\alpha)+\lambda_{\text {polA }}\right]}
$$

As

$$
\frac{\partial U_{p o l A}}{\partial I_{1}} * I_{1}=\left[-\left(\lambda_{p o l A}+1-\alpha\right)\right] I_{1}=0
$$

and $\lambda_{\text {polA }} \neq 0$, then $\lambda_{\text {polA }}=-(1-\alpha)$

So, we have for politician A:

$$
\begin{aligned}
\pi_{1}{ }^{\prime}\left(p_{1}{ }^{\text {polA }}\right) & =\frac{-\alpha S_{1}{ }^{\prime}\left(p_{1}{ }^{\text {polA }}\right)}{[(1-\alpha)-(1-\alpha)]} \\
\pi_{1}{ }^{\prime}\left(p_{1}{ }^{\text {polA }}\right) & \approx \infty
\end{aligned}
$$

or

This means that politician A picks $p_{1}$ closer to zero, regardless of costs. Observe that even the relative weights do not appear in the pricing rule. Politician A disregards his original preferences given in $\alpha$ and behaves as a pure populist politician as if $\alpha=1$. This makes sense since when the constraint is binding all first term profits are carried through the investment enforced by the regulator. This means that the net profit (deducting investment) in the first term is zero. Besides the fact that the investment does not matter for re-election, all first period profits are spent on investment financing, leaving entrepreneurs indifferent regarding regulated prices in the first period. So, the politician will only care about consumers, pressing for prices close to zero or even free provision. In this case, the investment effort of the firm will be meaningless to the politician since, given the electoral 
timing, it will not help him to be re-elected. The departure of politician A from the benevolent regulator result (eq. 8) is very strong, since the latter considered the following features in the pricing rule:

a)the basic short-run trade-off between profit gains $\left(\partial \pi_{1} / \partial p_{1}\right)$ and consumer loss $\left(\partial S_{1} / \partial p_{1}\right)$ from the price increase in period 1 ;

b)the effect of current prices on the current investment through the budget constraint and, therefore, on period 2 profits $\left(\delta \pi_{2} / \delta p_{1}\right)$ and consumer surplus;

c)the role of the intertemporal discount rate, $r$.

All these features are completely disregarded in the problem of politician $A$ of $\lambda_{\text {pola }} \neq 0$. Thus, agency independence from political influence matters a lot in this case, constraining the populist temptation of politician A.

Now, assume the second hypothesis that $\lambda_{\text {polA }}=0$. In this case, the constraint is not binding and the optimal regulated price for politician A is:

$$
\pi^{\prime}\left(p_{1}^{p o l A}\right)=\frac{-\alpha S_{1}{ }^{\prime}\left(p_{1}^{p o l A}\right)}{(1-\alpha)}
$$

Notice that the single difference of this rule from $\left(8^{\prime}\right)$ is the weight $\alpha$. If $\alpha=1 / 2$, there is no difference at all. The populist temptation observed in (10) does not occur here since there is a positive net profit (deducting investment) and thus increased prices implies more satisfaction to the entrepreneur that will be more willing to finance the campaign of politician $A$.

We turn now to the second assumption of tariff reviews occurring in the end of the second period.

\subsection{Politician B: Election at the End of the Second Period}

The second case holds when the tariff review occurs just after the election. In other words, elections and tariff reviews happen at the same time, with the second slightly after the first. Intuitively, it is common sense that this is usually the best scenario to avoid inappropriate political interference in tariffs. We argue that this statement is not always true, depending on the relative preferences of the politician given by $\alpha$.

In this case, consumers and firms look to the results obtained in the two periods before they vote. But, there is an important feature to be considered. The politician now fixes the price considering the consequences of his action on the consumer and on the firm two periods later. In this regard, profits and consumer welfare will be more important in the second period closer to the next election than in the first period. This can be captured by discounting the gains 
obtained by consumers and firms in the first period relative to the second one. Therefore, the objective function of politician $B$ will be such that he will maximize the following Lagrangean:

$$
\begin{aligned}
& U_{p o l B}=\frac{\left[\alpha S_{1}\left(p_{1}\right)+(1-\alpha)\left(\pi_{1}\left(p_{1}\right)-I_{1}\right)\right]}{1+r}+\left[\alpha S_{2}\left(p_{2}\left(x_{2}\left(I_{1}\right)\right)\right)+(1-\alpha) \pi_{2}\left(p_{2}\left(x_{2}\left(I_{1}\right)\right), x_{2}\left(I_{1}\right)\right)\right] \\
& +\lambda_{\text {polB }}\left(\pi_{1}\left(p_{1}\right)-I_{1}\right)
\end{aligned}
$$

Note that we assumed realistically that the agents value more the most recent (second) period than the older (first) one. Voters and entrepreneurs are more sensitive to what occurred more recently. The first order conditions are provided below:

$$
\begin{aligned}
& \frac{\partial U_{p o l B}}{\partial p_{1}}=\frac{\left[\alpha S_{1}{ }^{\prime}\left(p_{1}^{p o l B}\right)+(1-\alpha) \pi^{\prime}\left(p_{1}^{p o l B}\right)\right.}{1+r}+\lambda_{p o l B} \pi_{1}{ }^{\prime}\left(p_{1}{ }^{p o l B}\right)=0 \\
& \pi_{1}{ }^{\prime}\left(p_{1}{ }^{\text {polB }}\right)=\frac{-\alpha S_{1}{ }^{\prime}\left(p_{1}{ }^{p o l B}\right)}{\lambda_{p o l B}(1+r)+(1-\alpha)}
\end{aligned}
$$

As

$$
\begin{aligned}
& \frac{\partial U_{p o l B}}{\partial I_{1}} I_{1}=\left[\frac{-(1-\alpha)}{1+r}+(1-\alpha) \frac{d \pi_{2}}{d I_{1}}+\alpha \frac{d S_{2}}{d I_{1}}-\lambda_{p o l B}\right] I_{1}=0 \\
& \frac{\partial U_{p o l B}}{\partial \lambda_{p o l B}} \lambda_{p o l B}=\left(\pi\left(p_{1}\right)-I_{1}\right) \lambda_{p o l B}
\end{aligned}
$$

Once more, we have two hypothesis, $\lambda_{\text {polB }} \neq 0$ and $\lambda_{\text {polB }}=0$. In the first case, we get

$$
\lambda_{\text {polB }}=(1-\alpha)\left[\frac{d \pi_{2}}{d I_{1}}-\frac{1}{1+r}\right]+\alpha \frac{d S_{2}}{d I_{1}}
$$

and so,

$$
\pi_{1}{ }^{\prime}\left(p_{1}{ }^{p o l B}\right)=\frac{\frac{-\alpha S_{1}{ }^{\prime}\left(p_{1}{ }^{p o l B}\right)}{(1+r)}}{(1-\alpha) \frac{d \pi_{2}}{d I_{1}}+\alpha \frac{d S_{2}}{d I_{1}}}
$$


For $\alpha=1 / 2$, the price given in equation (12) will be higher than the preference of the benevolent regulator given in equation (8) and also for the first case of politician A. This relates to the fact that politician $B$ is obliged to look more to the long run than politician $A$, since he has a longer time until the next election where the benefits of a higher investment rate will have a greater weight. Moreover, Politician B, even recognizing that will loose some consumer support in the short run by allowing a higher price, knows that it is worthwhile to gain more in the period (the second) closer to elections. Thus, politician $B$ has a natural tendency to be more pro-firm in his price choice relatively to the benevolent regulator, even if his basic preference is a neutral one $(\alpha=0,5)$.

The key point is that both politicians decide in the beginning of the first period based on the foreseen satisfaction of consumers and campaign fund providers by the date of election. Politicians in this model will be concerned with people satisfaction in the meantime just as long as it influences their satisfaction by the moment of the election. ${ }^{12}$

In the case of the benevolent regulator, the difference arises only from the rate of time preference, $r$. If $r=0$ and politician $B$ is neutral regarding distribution $(\alpha=0,5)$, there would be no difference between politician $B$ and the benevolent regulator choice. Thus, agency independence would not be an issue.

If we have the case $r>0$, there is a pro-firm tendency of politician $B$. It can be offset if there is an original preference towards consumers $(\alpha>0,5)$. Indeed, given $r$, there is a value of $\alpha_{b}>0,5$ that makes the choice of price from politician $B$ in the first period equal to the benevolent regulator's. Thus if the true value of $\alpha$ is closer to $\alpha_{b}$ (politician B is populist, but not too much), independence will no longer be an issue in the regulatory design.

Comparing politicians $B$ to $A$, we note that the difference of the price rules emerges from the intertemporal discount rate and from the long run impact of the current investment over consumer surplus in period 2. The difference in the price rule between the two politicians is less sensitive to the original preference $\alpha$ than to the difference between both and the agency.

\footnotetext{
12 This captures the used allegation that politicians are used to forget them out of election time. Furthermore, it is plausible to assume an ad-hoc hypothesis that consumers and entrepreneurs have "differentiated memory" in the sense that the formers value relatively more the recent history than the latter. In the extreme case of "no long memory from consumers", it is easy to check in the model that politician B will pick $p_{1}^{\text {polB }}$ such that $\pi^{\prime}\left(p_{1}^{\text {polB }}\right)=0$ or $\pi^{*}\left(p_{1}{ }^{\text {polB }}\right)=\pi\left(p_{m}\right)$ or, in words, choose monopoly pricing in the first period.
} 
Now, turning to the case where $\lambda_{\text {polB }}=0$, we have that the investment financial constraint is not binding. In this case, we have once more

$$
\pi_{1}{ }^{\prime}\left(p_{1}^{p o l B}\right)=\frac{-\alpha S_{1}{ }^{p}\left(p_{1}^{p o l B}\right)}{1-\alpha}
$$

that is the same thing from politician $A$, where $p_{1}{ }^{\text {polB }}$ depends basically on who provides more gains to the politician in terms of increasing re-election probability. Note that this is the same result of politician A when his constraint is also non-binding in (10'). Moreover, if $\alpha=1$ / 2 , both politician pricing rules will be the same of the benevolent regulator. As there is no point in increasing the price for the sake of increasing the investment and improve the second period welfare of both players, there will be no meaning for politician $B$ to increase prices. He becomes less pro-entrepreneur than before in this case. But the main feature is that when the constraint is not binding in this model, the timing of elections and tariff reviews are meaningless for the sake of the result.

\subsection{Forward-Looking Voters}

At this point, it is relevant to ask what happens if voters have rational expectations and are forward-looking?

If elections occur between the tariff reviews (as for politician A), the lagrangean of the politician will be given by:

$$
U_{\text {polC }}=\left[\alpha S_{2}\left(p_{2}\left(x_{2}\left(I_{1}\right)\right)\right)+(1-\alpha) \pi_{2}\left(p_{2}\left(x_{2}\left(I_{1}\right)\right), x_{2}\left(I_{1}\right)\right)\right]+\lambda_{\text {polC }}\left(\pi_{1}\left(p_{1}\right)-I_{1}\right)
$$

The first order conditions are:

$$
\begin{aligned}
& \frac{\partial U_{p o l C}}{\partial p_{1}}=\lambda_{p o l C} \pi_{1}{ }^{\prime}\left(p_{1}{ }^{\text {polC }}\right)=0 \\
& \frac{\partial U_{\text {polC }}}{\partial \lambda_{\text {polC }}} \lambda_{\text {polC }}=\left(\pi\left(p_{1}\right)-I_{1}\right) \lambda_{\text {polC }} \\
& \frac{\partial U_{\text {polC }}}{\partial I_{1}} I_{1}=\left[(1-\alpha) \frac{d \pi_{2}}{d I_{1}}+\alpha \frac{d S_{2}}{d I_{1}}-\lambda_{p o l C}\right] I_{1}=0
\end{aligned}
$$


Seemingly, there are two hypothesis, $\lambda_{\text {polc }} \neq 0$ and $\lambda_{\text {polc }}=0$. In the first case, we get

$$
\pi_{1}{ }^{\prime}\left(p_{1}{ }^{\text {polc }}\right)=0
$$

The price settled by the regulator equals the monopoly price, which holds when the first period funding constraint binds. This happens because forward-looking voters disregards their first-period utility. So, the politician will be completely pro-entrepreneur. In the second case $\left(\lambda_{\text {polc }}=0\right)$, when the constraint does not bind, the politician is always able to increase his utility by making it binding, since consumers disregard their first-period surplus. Then, this hypothesis never holds in equilibrium.

If elections occur in the end of the second period, forward-looking agents would not have any function to maximize. We would have to add at least a third period, but the result would be basically the same of an election occurring just before tariff reviews: prices will be settled at the monopoly level. ${ }^{13}$ The main point is that forward-looking voters in this model always imply completely pro-entrepreneurs politicians, even more than in the case of politician B. Moreover, the syncronization or desyncronization of elections and tariff reviews does not matter for the behavior of forward-looking voters and thus for politicians in this particular context. This makes the question of synchronization and desyncronization uninteresting when voters are forward-looking in contrast with the hypothesis of backward-looking voters addressed in sub-sections " $b$ " and " $c$ ". Moreover, agency independence always matters for welfare when there are forward-looking voters, regardless of the original politicians preferences given by $\alpha$.

\section{Final Considerations}

The relevance of independence for institutional design of the regulatory agencies will usually depend on the relative preference of politicians toward consumers and firms. However, there are at least another two relevant dimensions of the problem that matter.

First, for the case of forward-looking voters, agency independence always matters, since there is a natural tendency of politicians to act completely pro-entrepreneur when settling tariffs or the $X$ factors.

\footnotetext{
${ }^{13}$ We could have added a third period in the model that would be only useful for this case (forward-looking and elections just after tariff reviews). However, as the intuition is straightforward and a third period would complicate the notation of the previous cases, we preferred to work with a two-period model.
} 
On the other hand, when there are backward-looking voters and there is a complete desynchronization of elections with tariff reviews, there are completely populist decisions from politicians, independent of their original relative preferences, $\alpha$. In this case, populist behavior emerges naturally from the different timing of elections and tariff reviews. The fear of political intervention in the regulatory procedures relates to an endogenous populist temptation and not from the capture of politicians by the firms.

The opposite conclusion emerges when elections and tariff review are synchronized (with the tariff review being slightly after the election). The tendency toward capture by firms is more prominent than populism. High positive discount rates makes independence more important and a bias toward consumers help to avoid distortions.

The model shows that it is not only a which matters for the case of an independent regulatory body. The timing of tariff reviews and elections matters as well. The direction of the original preferences $\alpha$ can compensate or exacerbate the problem raised by synchronization issues. When $\alpha$ compensates the problem, agency independence matter less and when $\alpha$ exacerbates the problem, agency independence matters more. We can summarize these conclusions in the following table for the case where the financial constraint of the investment is binding $\left(\lambda_{\text {poli }} \neq 0\right)$ :

Table 2 - Electoral Cycles and Price Cap Reviews

\begin{tabular}{|c|c|c|}
\hline & $\begin{array}{c}\text { Desinchronization } \\
\text { (Short-run Politician A) }\end{array}$ & $\begin{array}{c}\text { Sinchronization } \\
\text { (Long run Politician B) }\end{array}$ \\
\hline $\begin{array}{l}\text { Backw ard Looking Voters - } \\
\text { Pro-firm politician } \\
(\alpha<1 / 2)\end{array}$ & $\begin{array}{l}\text { Politician Bias Compensates Populism } \\
\text { Derived from Dessynchronization. } \\
\text { Agency independence matters less. }\end{array}$ & $\begin{array}{c}\text { Politician Bias exacerbates Pro-firm } \\
\text { preference derived from } \\
\text { sinchronization. A gency } \\
\text { independence matters more. }\end{array}$ \\
\hline $\begin{array}{l}\text { Backw ard Looking Voters - } \\
\text { Pro-consumer politician } \\
\qquad(\alpha>1 / 2)\end{array}$ & $\begin{array}{l}\text { Politician Bias exacerbates the } \\
\text { populist tendency derived from } \\
\text { Dessynchronization. A gency } \\
\text { independence matters more. }\end{array}$ & $\begin{array}{c}\text { Politician Bias Compensates Pro-Firm } \\
\text { Preference Derived from } \\
\text { Synchronization. A gency } \\
\text { independence matters less. }\end{array}$ \\
\hline Forward Looking V oters & There is always a pro-firm bias & There is always a pro-firm bias. \\
\hline
\end{tabular}

For backward-looking voters, when the investment financial constraint is not binding $\left(\lambda_{\text {poli }}=0\right)$, only $\alpha$ matters and any deviation of this variable from $1 / 2$ will mean a deviation of the politician rule from the benevolent regulator. 
For the purpose of assessing bill 3.337/2004 sent by the Executive Branch to the Congress in Brazil, we a remark based on the theoretical analysis of the paper. First, imposing syncronization of the agency commissioners mandate with the Presidential mandate, by changing all of them a little after the presidential election is, indeed, a good measure when politicians have a populist bias. If politicians have a pro-firm bias, this measure, on the contrary, exacerbates this problem of capture by regulated firms.

If the recent trend on Latin America of bringing to power governments with a relatively more populist tendency, the measure is interesting. On the other hand, if we believe that there is a long-run trend for voters becoming more mature in their choices as democracy evolves and thus, more forward looking, the opposite conclusion holds and the syncronization proposed is not appropriate.

\section{References}

ACTON, J .; VOGELSANG, I. Introduction. Rand J ournal of Economics. Autumn, Vol. 20. N. 3, 1989.

BEESLEY, M.; LITTLECHILD, S. Privatization: principles, problems and priorities. In: Beesley,M . ed. Privatization, Regulation and Deregulation. Routledge. Second Edition, 1997.

Grupo de Trabalho Interministerial: Análise e Avaliação do Papel das agências Reguladoras no Atual Arranjo Institucional Brasileiro. Presidência da República. Dez. 2003.

LAFFONT, J J .; TIROLE, J. A Theory of Incentives in Regulation and Procurement. Cambridge. MIT Press. 1993.

LEVY, B.; Spiller, P. The institutional foundations of regulatory commitment: a comparative analysis of Telecommunications regulation. In: Regulation, Institutions and Commitment: Comparative Studies of Telecommunications. Edited by Levy, B.; Spiller,P.1996.

MATTOS, C.C.; MUELLER, B. Regulando o Regulador: A Proposta do Governo e a ANATEL. Encontro Anual da ANPEC, J oão Pessoa/PB, Dezembro de 2004.

MITCHELL, B.; VOGELSANG, I. Telecommunications Pricing: Theory and Practice. Cambridge University Press. 1991.

NORDHAUS, W. The Political Business Cycles. Review of Economics Studies, 42, 1975.

OF TEL. A consultative document issued by the Director General of Telecommunications setting out proposals for future retail price and network charge controls. http:// www.oftel.gov.uk/publications/pricing/pcr1000.htm. O ctober 2000.

OGURA, L.M. Ciclos Eleitorais: Uma aplicação para a Economia Brasileira. Tese de Mestrado, Universidade de Brasília,2000.

PELTZMAN, S. Towards a More General Theory of Regulation, J ournal of Law and Economics, Vol. 19, 1976.

ROGOFF, K. Equilibrium Political Budget Cycles. American Economic Review , 80. 1990. ROGOFF,K; Sibert, A. Equilibrium Political Business Cycles. Review of Economic Studies, 55. 1988. 
SAPPINGTON, D.; WEISMAN, D. Designing Incentive regulation for the telecommunications industry. AEI Studies in Telecommunications Deregulation. The AEI Press. 1996.

SHEPSLE, K.A.; WEINSGAST, B.R. The Institutional Foundations of Committee Power. American Political Science Review, Vol 81 N 1 March, 1987.

VICKERS,J ; YARROW, G. Privatization: An Economic Analysis. Cambridge, MA: MIT Press. 1988.

Recebido em 23/06/2008.

Aceito em 14/07/2008. 